Titulo do Trabalho

\title{
JOVEM FLORESTAL: A SEMENTE EM SUAS MÃOS.
}

Nome do Autor (a) Principal

Naiara Vieira e Vieira

Nome (s) do Co-autor (a) (s)

Gisele Lamberti Zanirato \& Guilherme Malheiros Gião Filho.

Nome (s) do Orientador (a) (s)

Sérgio Valiengo Valeri

Instituição ou Empresa

Universidade Estadual Paulista - Unesp

Instituição (s) de Fomento

Pró-reitoria de Extensão Universitária - Proex Unesp

E-mail de contato

nvieira_bio@yahoo.com.br

Palavras-chave

Inclusão social. Mudas florestais. Extensão Universitária.

\section{INTRODUÇÃO}

A questão ambiental pede hoje uma reformulação de valores, de percepção e de conceitos. Necessita de algo que se possa contrapor a uma 
visão de mundo que vem fragmentando a realidade, separando o homem da natureza. A temática ambiental deve propiciar reflexão, sobretudo no que se refere à melhoria da qualidade do ensino, quando busca trabalhar conteúdos compatíveis à realidade escolar de seus alunos (Bortolozzi, 1999).

O conhecimento e a valorização ambiental são de grande valia para o bem-estar social. Promover a percepção da importância do meio ambiente cumpre, segundo SORRENTINO (2002), a função social de viabilizar que a comunidade detenha conhecimentos necessários para, como cidadãos, decidir sobre os mais diversos problemas acerca das questões socioambientais.

O dia-a-dia de educadores e educadoras ambientais que dedicam-se a empreender ações voltadas à conservação e desenvolvimento sócio-ambiental, envolve uma multiplicidade de desafios, como o contato com as comunidades, a formação de parcerias e o desenvolvimento de atividades criativas (Dietz \& Tamaio, 2000).

Os projetos de extensão universitária são uma poderosa ferramenta para aqueles, alunos e professores, que desejam realizar atividades nesta área, dando a oportunidade de praticar o desenvolvimento e aplicação de atividades, além de, promover o convívio e a integração entre comunidade e a instituição de ensino. Sendo uma prática enriquecedora, fonte de conhecimento social e científico, tanto para os universitários quanto para a comunidade em geral.

O "Jovem Florestal: a semente em suas mãos", um projeto de extensão universitária financiado pela PROEX - Pró-reitoria de Extensão Universitária da Unesp, vem sendo realizado há alguns anos, contando com a participação de jovens que têm interesse em aprender um pouco mais sobre o meio ambiente, auxiliando-os em sua profissionalização, produção de mudas e reflorestamento, como forma de inclusão social e conscientização ambiental.

\section{OBJETIVO GERAL}


1) Valorização do ambiente florestal e percepção de seus benefícios. 2) Desenvolver a arte da observação, da dúvida, da crítica e da memória; a arte de aprender com a natureza: trabalho em grupo, ajuda mútua, respeito às diferenças, humanismo e altruísmo, usando os conhecimentos das relações existentes entre as espécies animais e vegetais. 3) Desenvolver a capacidade de gerenciamento das emoções, da reflexão, interiorização, da responsabilidade e das conseqüências do comportamento, usando os princípios de escolha, gerenciamento do "Eu", pensar antes de agir, respeito pelas emoções do próximo, princípios de prevenção de acidentes e respeito pela vida.

\section{OBJETIVOS ESPECÍFICOS}

Complementar as atividades de jovens com idade entre 11 e 16 anos, de ambos os sexos, ligados ao Projeto Social da Prefeitura do Município de Jaboticabal - "Caminhando Para o Futuro" - e de pessoas especiais, jovens e adultos, também de ambos os sexos, assistidos pela APAE - Associação de Pais e Amigos Especiais, do município de Taiaçu. Auxiliando em sua profissionalização, produção de mudas e reflorestamento, como forma de inclusão social e conscientização ambiental. Além de formar cidadãos mais conscientes e multiplicadores de valores ambientais. Bem como promover a troca de conhecimentos entre os Jovens e os universitários, a aproximação entre comunidade/universidade, além da sensibilização dos universitários em relação à situação social e educacional da região.

\section{METODOLOGIA}


Este ano projeto conta com duas etapas, estabelecida de acordo com o ano letivo das escolas municipais. A primeira, já finalizada, do início de março ao início de julho, e a segunda, do início de agosto ao início de dezembro. No primeiro semestre do ano de 2010 participaram do projeto 75 jovens de ambos os sexos, com faixa etária entre 11 e 16 anos, vinculados ao projeto social da Prefeitura Municipal de Jaboticabal-SP: "Caminhando para o futuro". Foram formados 5 grupos de 15 jovens, sendo que cada grupo participava de uma atividade por semana. Assim, as atividades foram desenvolvidas no período da manhã, com duração de $2 \mathrm{~h}$, todos os dias da semana.

Além disso, semanalmente, participaram do projeto 20 pessoas portadoras de necessidades especiais, jovens e adultos de ambos os sexos, assistidas pela APAE - Associação de Pais e Amigos Especiais - do município de Taiaçu/SP. Essas atividades foram desenvolvidas uma vez por semana, durante duas horas.

As atividades foram realizadas nas dependências do Viveiro Experimental de Plantas Ornamentais e Florestais da Unesp/FCAV, campus de Jaboticabal, conhecido como "Horto da Unesp". Planejadas e desenvolvidas pelos alunos voluntários do curso de Ciências Biológicas desta mesma instituição - Naiara Vieira e Vieira, Gisele Lamberti Zanirato e Guilherme Malheiros G. Filho -, sob orientação do Prof. Sérgio Valiengo Valeri, com auxilio dos viveirista.

Os Jovens participaram de aulas prático-teóricas sobre noções ecológicas básicas, - como: formação, dispersão e germinação de sementes; formações florestais; diferenciação de espécies, etc. - ministradas pelos alunos voluntários. Realizaram, também, atividades práticas, como: coleta e beneficiamento de sementes, produção de mudas, dinâmicas de grupo, oficinas, jogos cooperativos com vários temas de educação ambiental com enfoque em fauna, flora, água e lixo. 
Os jovens aprenderam, na primeira etapa - março a julho de 2010-, a preparar substrato, preencher recipientes com substratos, realizar semeadura, repicagem, irrigação e condução das mudas florestais no viveiro da Faculdade.

Dentre os 95 jovens participantes do projeto no ano de 2010, receberão o Atestado de Participação no projeto, assinado pelo Coordenador e ViceDiretora no exercício da Direção, todos aqueles que continuarem freqüentando as atividades até a data prevista para a finalização da segunda etapa, em novembro de 2010.

\section{RESULTADOS}

No decorrer da primeira etapa do projeto no ano de 2010, muitos jovens demonstraram grande interesse por atividades de campo, reclamaram sobre a falta deste tipo de atividade nas escolas e afirmaram aprender muito mais facilmente na prática.

Embora muitos dos jovens já houvessem tido contatos prévios com remanescentes florestais, pareciam nunca haver observado com atenção as diferenças existentes entre as espécies e sua relação com o ambiente, e consideravam-nas como um indivíduo, não como parte de em ecossistema complexo.

Demonstraram capacidade de identificação de algumas espécies e dos respectivos empregos dados pelo Homem, principalmente de espécies utilizadas como fonte de alimento.

Apesar de afirmarem que as plantas têm um ciclo de desenvolvimento, pareciam não considerá-las como seres vivos. Por exemplo: saber que as 
plantas se reproduziam e que existiam órgãos femininos e masculinos ou que, em sua maioria, são capazes de produzir seu próprio alimento por meio da fotossíntese e não o absorvem do solo, Ihes causou muito espanto.

Pode-se, também, observar claramente a maneira como os jovens se entusiasmavam em realizar as atividades, talvez pela tranqüilidade do local e pela forma como eram conduzidas as "aulas", forma muito diferente do método expositivo, geralmente predominante nas salas de aula. O contato com o objeto estudado pareceu Ihes facilitar o entendimento.

Também observou-se, ao longo do semestre, um aumento significativo do interesse dos jovens pelas ciências e pelo ensino universitário. Muito provavelmente 0 fato de visitar frequentemente as dependências da universidade e manter um contato com seus alunos, professores e funcionários, desmistificou as noções que, provavelmente, tinham em relação à instituição.

Conclui-se, portanto, que o projeto trouxe muitos ganhos tanto à instituição quanto a comunidade, atingindo completamente todos os seus objetivos, sociais e educacionais. Provando que a instituição tem condições de auxiliar na inclusão social de jovens carentes e portadores de necessidades especiais. Verificou-se, ainda, que o projeto auxilia nas seguintes características e comportamentos dos Jovens: disciplina, capacidade de desenvolver atividades em grupo, auto-estima, criatividade, raciocínio e memorização.

\section{REFERÊNCIAS}


BORTOLOZZI, A. Comunicação, Ensino e Temática Ambiental. Comunicação \& Educação, São Paulo, (14) : 42 a 48, jan./abr. 1999.

DIETZ, L.A. \& TAMAIO, I. (coor.) Aprenda Fazendo: apoio aos processos de Educação Ambiental. Brasilia, WWF Brasil, 2000.

SORRENTINO, M. Desenvolvimento sustentável e participação: algumas reflexões em voz alta. In: LOUREIRO, Frederico B; LAYARGUES, Philippe P.; CASTRO, Ronaldo S. (orgs.). Educação ambiental: repensando o espaço da cidadania. São Paulo: Cortez, 2002. 